10IKC-204

\title{
MULTI-STAGE METASOMATISM OF A ROBERTS VICTOR ECLOGITE LINKED TO THE FORMATION AND DESTRUCTION OF DIAMOND
}

\author{
RICHES ${ }^{1 *}$, A.J.V., PEARSON ${ }^{1}$, D.G., STERN ${ }^{1}$, R.A., ICKERT ${ }^{1}$, R.B., \\ Kjarsgaard $^{3}$, B. A., Jackson ${ }^{3}$, S. E., and ISHIKAWA ${ }^{2}$, A. \\ ${ }^{1}$ Dept. of Earth and Atmospheric Sciences, University of Alberta, Edmonton, Canada. \\ ${ }^{2}$ Dept. of Earth Science and Astronomy, The University of Tokyo at Komaba, Tokyo, Japan. \\ ${ }^{3}$ Geological Survey of Canada, Ottawa, Canada. *Corresponding author ariches@ualberta.ca
}

\section{INTRODUCTION}

Eclogites ( \pm pyroxenite) may host significant quantities of diamonds in some portions of sub-continental lithospheric mantle (e.g., Orapa, Magondi Mobile Belt; Shee and Gurney, 1979; Argyle, Halls Creek Mobile Zone; Jaques et al., 1989; Nyurbinskaya, Siberian Craton; Spetsius et al., 2008; Riches et al., 2010), and it is well established that the xenolith population of the Roberts Victor kimberlite is eclogite-rich, as eclogites account for $>95 \%$ of the xenoliths from this pipe (MacGregor and Carter, 1970; Hatton, 1978). Eclogites are broadly basaltic rocks that are widely considered to represent subducted crustal materials derived from oceanic lithosphere (e.g., Snyder et al., 1997; Jacob, 2004; Pearson et al., 2003; Taylor et al., 2003a; Riches et al., 2010). However, some Group-I eclogite xenoliths have textural features (including banding and zonation of modal abundances) that may not be explained by garnet formation during high-pressure transformation alone (e.g., Hatton and Gurney, 1987; Ishikawa et al., 2008a-b; Gréau et al., 2011).

Oxygen isotope compositions of eclogitic and pyroxenitic garnets have often been interpreted as a robust tracer of protolith materials (e.g., Snyder et al., 1997; Jacob et al., 2004, 2005), and garnet $\mathrm{a}^{18} \mathrm{O}$-values significantly above $5.9 \%$ are often cited as evidence supporting a shallow origin for eclogites (e.g., Jagoutz et al., 1984;
Snyder et al., 1997; Jacob et al., 2004; Spetsius et al., 2008; Riches et al., 2011). Recent studies have questioned the robust nature of garnet $\mathrm{a}^{18} \mathrm{O}$-values (Gréau et al., 2011); these authors reported oxygen
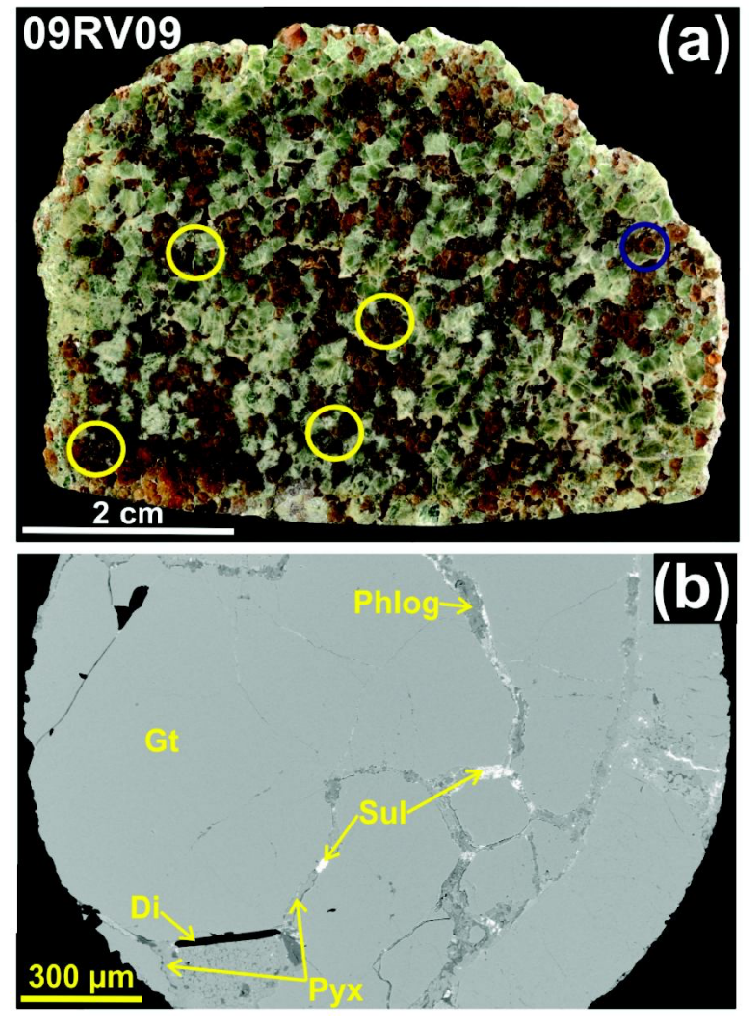

Figure 1: Photographic image of a large polished slice (a), and BSE image of a diamond-bearing portion (b) of a phlogopite-bearing Gtwebsterite (09RV09) from the Roberts Victor kimberlite. In (a), circles outline sub-regions selected for in situ study, and the blue circle marks the diamond bearing portion shown in (b). $\mathrm{Di}=$ diamond, $\mathrm{Gt}=$ garnet, $\mathrm{Phlog}=$ phlogopite, $\mathrm{Pyx}=$ pyroxene, $\mathrm{Sul}=$ sulphide . 


\section{0 $^{\text {th }}$ International Kimberlite Conference, Bangalore - 2012}

isotope data for multiple garnet grains of GroupI and Group-II eclogites from Roberts Victor, and suggested that garnet $\ddot{a}^{18} \mathrm{O}$-values are correlated with incompatible-element abundances.

We provide the first in situ measurements of $\ddot{a}^{18} \mathrm{O}$ compositions (determined by ionmicroprobe) in garnet adjacent to diamond, and these data are supplemented by in situ major- and trace-element abundance data of garnets and coexisting phases. Our results show that; 1) $\mathrm{a}^{18} \mathrm{O}$ values do not show measurable inter- and intragrain oxygen-isotope variation in Gt-rich and Cpx-rich portions ( \pm diamond \pm phlogopite) of 09RV09, and 2) garnet $\ddot{a}^{18} \mathrm{O}$-values do not correlate with major- and trace-element abundances and inter-element ratios.

\section{RESULTS}

\subsection{Petrography and Mineralogy}

A diamond- and phlogopite-bearing Gtwebsterite xenolith, 09RV09, of Roberts Victor, Kaapvaal Craton, contains regions with variable proportions of garnet and clinopyroxene (Fig. 1a). Garnet (up to $1.5 \mathrm{~mm}$ in maximum dimension) and clinopyroxene crystals (up to $2 \mathrm{~mm}$ in maximum dimension) dominate the matrix of this sample ( $>90$ vol. \%), and lesser amounts of phlogopite (up to $1 \mathrm{~mm}$ in maximum dimension), sulphide (generally $<0.5 \mathrm{~mm}$ ), clino- and orthopyroxene ( $<0.5 \mathrm{~mm}$ maximum dimension), and diamond (up to $800 \mu \mathrm{m}$ in maximum dimension in the studied sections) generally occur as interstitial phases. Polycrystalline diamondaggregates (up to $2 \mathrm{~mm}$ in maximum dimension) are located in other portions of 09RV09, and are not the focus of this work. In contrast to all Siberian diamondiferous-eclogites studied to date that do not contain diamond in contact with garnet (Taylor and Anand, 2004; Spetsius and Taylor, 2008), a $280 \mu \mathrm{m}$ elongate diamond (Fig. 1b) in 09RV09 is in direct contact with garnet along 200 $\mu \mathrm{m}$ of its length. Calcium-proportions (Ca\#= $100 \mathrm{Ca} /\left[\mathrm{Ca}+\mathrm{Mg}+\mathrm{Fe}^{\text {total }}\right]$ ) and $\mathrm{Mg} \#$ (where $\mathrm{Mg} \#=$ $\left.100 \mathrm{Mg} /\left[\mathrm{Mg}+\mathrm{Fe}^{\text {total }}\right]\right)$ of all studied 09RV09 garnets define an antithetic correlation over a moderate range of $\mathrm{Ca \#}$ (9.01 to 10.7 ) and $\mathrm{Mg \#}$ (76.7 to 80.0). Garnets associated with phlogopite have $\mathrm{Mg} \#>77.5$ whereas garnets in phlogopitefree zones have $\mathrm{Mg} \#<77.5$, and all garnets record modest intra-grain variations in $\mathrm{Ca} \#$ ( \pm 0.4 to 1.0 units) with no systematic core to rim trend.

\subsection{Trace-Element Compositions}

Garnets of 09RV09 are very consistent in their trace element compositions. They are exclusively LREE-depleted $\left([\mathrm{La} / \mathrm{Yb}]_{\mathrm{N}}=0.002\right.$ to 0.007 ) with HREE-abundances of $\sim 9.5$ to $13 * \mathrm{CI}-$ chondrite (Fig. 2a), and $\left[\mathrm{Eu} / \mathrm{Eu}^{*}\right]_{\mathrm{N}}$ values of 0.99 to 1.30. Sinusoidal REE-patterns were not observed in garnet grains, including those in close association with diamond. High field strength element contents of 09RV09 garnets are broadly similar to those of some rutile-free eclogites (e.g., Jacob and Foley, 1999), with $[\mathrm{Zr} / \mathrm{Hf}]_{\mathrm{PM}}$ values ranging from 1.4 to 4.0 .

\subsection{In situ Oxygen Isotope Data}

Oxygen isotope compositions of garnets in 09RV09 are all above 'typical' mantle values, ranging from $6.2 \%$ to $6.8 \%$ (Fig. $2 \mathrm{~b}$ ), and analytical uncertainties are generally 0.3 to $0.4 \%$ o $2 \delta_{\text {stdev }}$ (combined internal and external precisions). The mean, mode, and median values of these data (a total of 94 points on 8 garnets from a range of textural locations) are within uncertainty of one another (6.5\%o, 6.6\%o, 6.5\%o, respectively), and no detectable inter- and intra-grain ${ }^{18} \mathrm{O}$ variations are recorded in garnets of this xenoliths.

\section{SUMMARY}

Previous studies of Group-I eclogites (including Gt- websterites) have noted striking 
modal variations that may be related to metasomatic processes (e.g., Hatton and Gurney, 1987; Ishikawa et al., 2008a-b; Gréau et al., 2011). Our in situ investigation of a single diamondiferous Roberts Victor Gt-websterite with garnet $\ddot{a}^{18} \mathrm{O}$-values above the mantle-range shows no correlation between major- and trace-element abundances and oxygen isotope compositions. This information suggests that metasomatism by small-volume fluids and/or melts potentially linked to the formation and/or destruction of
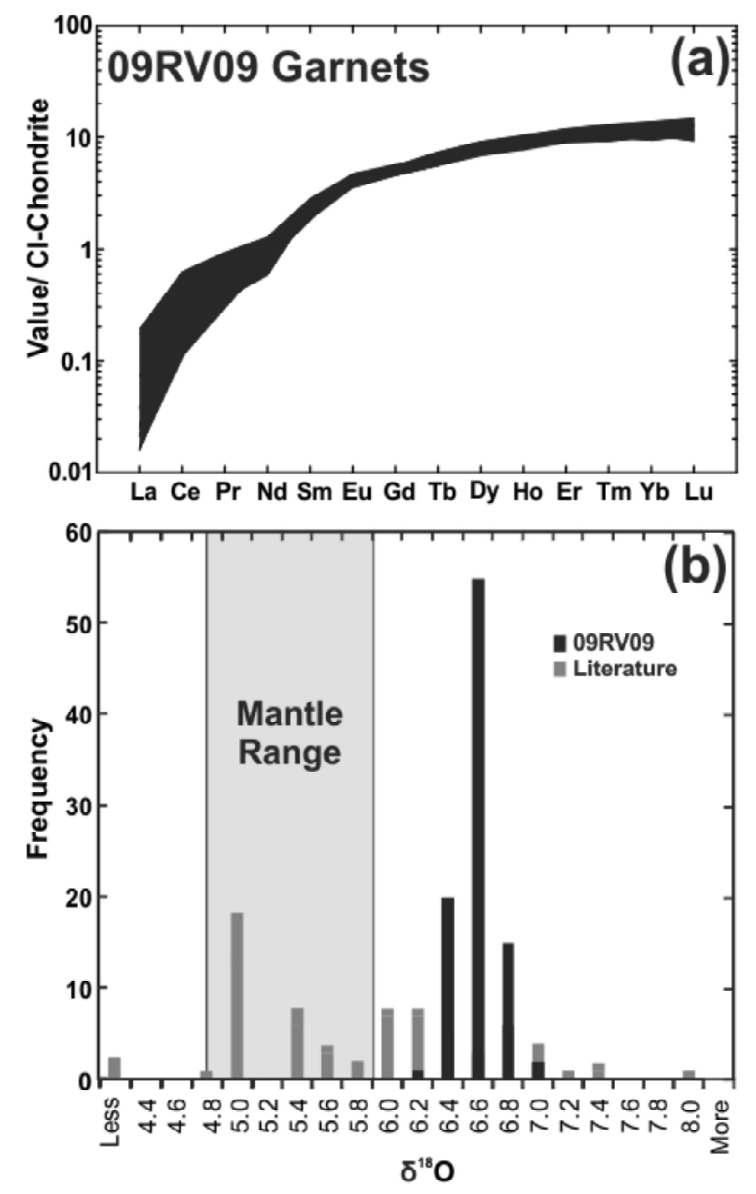

Figure 2: Rare-earth-element (REE) contents of 09RV09 garnets determined by LA-ICP-MS (a) normalized the CI-chondrite value of McDonough and Sun (1995), and (b) oxygen isotope compositions of garnets determined in this study of a single xenolith compared to those determined for garnets of numerous xenoliths in previous publications (Garlick et al., 1971; Ongley et al., 1987; Caporuscio, 1990; Schulze et al., 2000; Gréau et al., 2011) and the range defined for 'typical' mantle garnets (Valley et al., 1998). diamonds (e.g., Deines et al., 1987; Taylor et al., 1996,1998,2003b; Ishikawa et al., 2008a-b; Izraeli et al., 2001; Navon et al., 2003; Klein-BenDavid et al., 2006, 2010; Tomlinson et al., 2006; Rege et al., 2008; Liu et al., 2009) has not created secondary $\ddot{a}^{18} \mathrm{O}$-signatures. These results are consistent with previous studies (e.g., Snyder et al., 1997; Jacob, 2004,2005; Spetsius et al., 2008; Riches et al., 2011), which indicated that garnet oxygen isotope compositions provide a robust trace of the source lithology. Given the ancient ages (2.7-3.5 Ga) determined for several Roberts Victor eclogite samples (e.g., Shirey et al., 1999ab, 2001) this information is of great importance for understanding the origin and evolution of Archean sub-continental lithospheric mantle.

\section{AKNOWLEDGEMENTS}

We thank John Gurney for donating the Gtwebsterite sample used in this study.

\section{References}

Caporuscio, F. A., 1990. Lithos, 25(1-3), 203-210.

Deines, P., Harris, J. W., and /Gurney, J. J., 1987. GCA, 51, 1227-1243.

Garlick, G. D., MacGregor, I. D., and Vogel, D. E., 1971. Science, 172, 1025-1027.

Gréau, Y., Huangm J.-X., Griffin, W. L., Renac, C., Alard, O., and O'Reilly, S. Y., 2011, GCA, 75, 6927-6954.

Hatton, C. J., 1978. Ph.D thesis, Univ. Cape Town.

Hatton, C. J., and Gurney, J. J., 1987, In: Mantle Xenoliths.

Ishikawa, A., Pearson, D. G., Maruyama, S., Cartigny, P., Ketcham, R. A., and Gurney, J. J., 2008. $9^{\text {th }}$ IKC, abstract \#00078.

Ishikawa, A., Pearson, D. G., Maruyama, S., de Bruin, D., and Gurney, J J., 2008, $9^{\text {th }}$ IKC, abstract \#00079.

Izraeli, E. S., Harris J. W., and Navon O., 2001. Brine inclusions in diamonds: a new upper mantle fluid. Earth Planet. Sci. Lett., 187(3-4), 323-332.

Jacob, D. E., 2004. Lithos, 77, 295-316.

Jacob, D. E., and Foley, S. F., 1999. Lithos, 48, 317 336. 


\section{0 $^{\text {th }}$ International Kimberlite Conference, Bangalore - 2012}

Jacob, D. E., Bizimis, M., Salters, V. J. M., 2005. Contrib. Mineral. Petrol., 148, 707-720.

Jagoutz, E., Dawson, J. B., Hoernes, S., Spettel, B., and Waenke, H., 1984. In: Lunar and Planet. Inst. Workshop on Early Earth., pp. 40-41.

Jaques, J. L., Hall, A. E., Sheraton, J. W., Smith, C. B., Sun, S.-s., Drew, R. M., Foudoulis, C., and Ellingsen, K., 1989, In Kimberlites and Related Rocks: Their Crust Mantle Setting.

Klein-BenDavid, O., Izraeli, E S., Hauri, E., and Navon, O., 2004. Mantle fluid evolution - a tale of one diamond. Lithos 77, 243-253.

Klein-BenDavid, O., Pearson, D. G., Nowell, G. M., Ottley, C., McNeill, J. C. R., and Cartigny, P., 2010. Mixed fluid sources involved in diamond growth constrained by $\mathrm{Sr}-\mathrm{Nd}-\mathrm{Pb}-\mathrm{C}-\mathrm{N}$ isotopes and trace elements. Earth Planet. Sci. Lett., 289, 123-133.

Liu, Y., Taylor, L. A., Sarbadhikari, A. B., Valley, J. W., Ushikubo, T., Spicuzza, M. J., Kita, N., Ketcham, R. A., Carlson, W., Shatsky, V., Sobolev, N. V., 2009. Lithos, 112, 1014-1024.

MacGregor, and Carter, 1970. Phys. Earth Planet. Interiors, 3, 391-397.

McDonough, W. F., and Sun, S.-s., 1995, Chem. Geol., $120,223-253$.

Navon, O., Izraeli, E. S., and Klein-BenDavid, O., 2003. Fluid inclusions in diamonds: the carbonatitic connection. $8^{\text {th }} \mathrm{IKC}$, abstract \#107.

Ongley, J. S., Basu, A. R., and Kyser, T. K., 1987. EPSL, 83(1-4), 80-84.

Pearson D. G., Canil, D., and Shirey, S. B., 2003. In: Treatise on Geochemistry.

Riches, A. J. V., Liu, Y., Day, J, M. D., Spetsius, Z. V., and Taylor, L. A., 2010. Lithos, 120, 368-378.

Schulze, D. J., Valley, J. W., and Spicuzza, M. J., 2000. Lithos, 54(1-2), 23-32.

Shee, S. R., and Gurney, J. J., 1979, In: The Mantle Sample: Inclusions in Kimberlites and Related Rocks.
Shirey, S. B., Wiechert, U., Carlson, R. W., Gurney, J. J., and Van Heerden, L., 1999a. $9^{\text {th }}$ Annual Goldschmidt Conf., abstract \# 7630.

Shirey, S. B., Carlson, R. W., Gurney, J. J., and Van Herden, J., 1999b. $7^{\text {th }}$ IKC,

Shirey, S. B., Carlson, R. W., Richardson, S. H., Menzies, A., Gurney, J. J., Pearson, D. G., Harris, J. W., and Wiechert, U., 2001. Geophys. Res. Lett., 28, 2509-2512.

Snyder, G. A., Taylor, L. A., Crozaz, G., Halliday, A. N., Beard, B. L., Sobolev, V. N., and Sobolev, N. V., 1997. JPET, 38(1), 85-113.

Spetsius, Z. V., Taylor, L. A., Valley, J. W., Deangelis, M. T., Spicuzza, M., and Ivanov, A. D., 2008. Eur. J. Mineral., 20, 375-385.

Spetsius Z. V., and Taylor, L. A., 2008. Diamonds of Siberia, Photographic Evidence for their Origin.

Taylor, L. A., and Anand, M., 2004. Chemie der Erde, 64, 1-74.

Taylor, L. A., Snyder, G. A., Crozaz, G., Sobolev, V. N., Yefimova, E. S., Sobolev, N. V., 1996. Earth Planet. Sci. Lett., 142(3-4), 535-551.

Taylor, L. A., Milledge, J. H., Bulanova, G. P., Snyder, G. A., and Keller, R. A., 1998. Metasomatic Eclogitic Diamond Growth: Evidence from Multiple Diamond Inclusions. Int. Geol. Rev., 40(8), 663-676.

Taylor, L. A., Snyder, G. A., Keller, R., Remley, D. A., Anand, M., Wielsi, R., Valley, J. W., and Sobolev, N. V., 2003a. Contrib. Mineral. Petrol., 145, 424443

Taylor, L. A., Anand, M., Promprated, P., Floss, C., and Sobolev, N. V., 2003b. The significance of mineral inclusions in large diamonds from Yakutia, Russia. Amer. Mineral., 88(5-6), 912-920.

Tomlinson, E. L., Jones, A. P., and Harris, J. W., 2006. Co-existing fluid and silicate inclusions in mantle diamond. Earth Planet. Sci. Lett., 250, 581-595.

Valley, J. W., Kinny, P. D., Schulze, D. J., and Spicuzza, M. J., 1998, CMP, 133, 1-13. 